\title{
THE INFLUENCE OF THE PRESENCE OF VEGETATIONS IN FLOODPLAINS ON FLOOD RISKS
}

\author{
Natalia Walczak ${ }^{1}$, Mateusz Hammerling ${ }^{1}$, Marcin Spychała' ${ }^{1}$ Jakub Nieć ${ }^{1}$ \\ 1 Department of Hydraulic and Sanitary Engineering, Faculty of Land Reclamation and Environmental Enginee- \\ ring, University of Life Sciences in Poznan, Piątkowska 94E Str., 60-649 Poznań, Poland, e-mail: natwal@wp.pl; \\ mhammer@up.poznan.pl; marsp@up.poznan.pl; jniec@up.poznan.pl
}

Received: 2015.09.14

Accepted: 2015.10.06

Published: 2015.11.10

\begin{abstract}
The movement of water on flood areas depends mainly on the geometric parameters of vegetation, which as a dynamic factor causes a high changeability of flow conditions during the year. The actual ecological trend, whereby there is a tendency to leave the plants in the floodplain, imposes the necessity on engineers to develop accurate methods of determining the effect of vegetation on what used to be once a commonly occurring flood risk. According to the report on national security risk, elaborated by the Government Security Centre, flooding is the most common such risk. This is most likely to occur among all the risks included in the National Crisis Management Plan and brings the greatest number of negative effects. In order to mitigate the negative phenomena related to floodplains, the methodology and calculation of the average flows, using the Maninng and Darcy-Weisbach models is presented.
\end{abstract}

Keywords: flood area, flow velocity, resistance coefficient, roughness coefficient, vegetation.

\section{INTRODUCTION}

Looking at the river one pays attention mainly to the strength of the drift, the size of the trough and shape of the banks. It is clear that the attributes of the channel and the flow rate may affect the functioning of ecosystems of flowing water and this in turn may affect the risk of flooding. Physical processes occurring in the river valleys are the subject of ongoing analysis of hydrologists and geomorphologists. Increasingly, this area is also intensively studied by hydrobiologists. The distribution of vegetation in the floodplain is constantly changing and the changing structure of growth affects the hydromorphology of the river valley. Aquatic plants each year during the vegetation season pass through the phase of growth, flowering and undergo intensive vegetative development and decay. The duration of such phases is variable and depends on environmental factors. The intensity of aquatic vegetation growth is mainly an individual characteristic of each river.
This also applies to slopes and floodplains in the given cross-section. The highly complex ecosystem of the river can be divided into the main trough, the waters beneath, the above-water slope and floodplains.

\section{LOCATION OF VEGETATION AREAS}

On the slopes of the banks of the main channel and floodplain, vegetation occurs in a form of diverse grasses, perennials, reeds, sedges, shrubs and trees. Determination of resistance to motion for the calculation of the channel capacity of great waters requires the introduction of a vegetation classification. Bretschneider and Schulz [1985] divided the vegetation in terms of low, medium and high. Currently, the most common division of vegetation depends on the degree of submergence and its deformation under the influence of water flow.

Vegetation can be divided into partially and fully submerged, taking into consideration the 
depth of immersion. The partially submerged plants are trees and large bushes of a height about 3-5 m. At the shallow depths of water on the floodplain there can also be found high perennials, sedges and reeds may be partially submerged. Depending on the deformation caused by the flow, the vegetation can be divided into [Kałuża 2000]:

- rigid (non-deformable),

- flexible (elastic and temporary deformation),

- degraded (irreversible deformation).

The first group includes partially submerged trees and shrubs, the second - submerged sedges and reeds, and the third group - grasses and perennials. Plants of the third group can undergo degradation in two ways. During the growing season, during the passage of flood wave, floral elements bend permanently and lie on the ground surface. However, after the flow decrease, they may partially recover to their initial state (shape). During the non-growing season during the winter - spring floods, dry grass and reeds elements are broken and irreversibly damaged.

Natural floodplains are covered with various types of vegetation that are essential to the transport of water, suspensions, nutrients and contaminants [Nepf and Vivoni 1999,]. Vegetation is therefore a key factor in the flow system, transport and geomorphology of river valleys [Tsujimoto et al. 1992].

Many studies have been carried out on the impact of vegetation on flow in recent years. To a large extent these were laboratory tests. Defina and Bixio (2005) systemized recent research in past decades carried out on hydraulic water flow conditions in the area covered by vegetation. These authors divided these into laboratory research (conducted with natural vegetation, artificial elastic vegetation, elastic and rigid artificial vegetation) and field research. Investigations of the effect of natural vegetation on the flow in the laboratory conditions at its complete submergence were conducted by Gambi et al. [1990] for grasses, Andersen et al. [1996] for very high seaweed, Meijer and van Velzen [1999] for reed and by Nepf and Koch [1999] for the three different types of marine and wetland vegetation. Also, Stephan and Gutknecht [2002] performed laboratory measurements of natural grass vegetation. In contrast, Fathi-Moghadam and Kouwen [1997] performed laboratory tests for the elements of natural vegetation, partially submerged, using, among others, branches of young pines. Järvelä [2002, 2003] applied grass, branches of willows and other veg- etation frequently occurring in floodplains to the laboratory test at different water depths.

The use of natural vegetation in the laboratory is troublesome, mainly due to its low stability, which does not allow for a multiple repetition of experiments. In addition, the geometric specificity of vegetation (the variability of the shape of the stem and leaves) makes the analysis of the results much more difficult. In order to eliminate this difficulty in the laboratory investigation, many researchers replace natural vegetation with elements imitating natural plants having a similar elasticity. Wu et al. [1999] used a natural material for testing - horse hair, Nepf and Vivoni [1999] instead of the spring vegetation (grass) - artificial elements made of PVC, Baptist [2003] - artificial elastic aquarium plants, and Wilson et al. [2003] - elements made of PVC imitating parts of plant, with and without leaves, which corresponded to the natural water vegetation of the kelp family (Laminaria hyperborea). Kubrak [2007] and Kubrak et al. [2008] conducted laboratory tests using the elastic and rigid element made of PVC.

In an experimental study the natural vegetation is replaced also by simple, cylindrical plastic elements [Shimizu and Tsujimoto 1994, Nepf 1999, Negma et al. 2002, Rowiński and Kubrak 2002, James et al. 2004, 2008, Huthoff et al. 2007], rigid and wooden [Lopez and Garcia 2001, Stone and Shen 2002, Ghisalberti and Nepf 2004], cylindrical metal stakes [Yordanova and James 2003] or artificial, spherical [Righetti and Armanini 2002, Kałuża 2000]. Rameshwaran and Shiono [2007] performed laboratory tests, dividing the open channel into two zones: the main riverbed and floodplains. There was no vegetation in the main trough, and floodplains were characterized by different slopes. In such a model they performed the measurements of water velocity on flood plains, with imitation of vegetation in a form of vertical bars.

On the basis of the studies reported in the literature, it can be seen that many researchers decided to analyze the impact of vegetation on flow directly (in situ) in the environment. Leonard and Luther [1995], and Howe and Rodriguez [2006] studied the effect of vegetation in areas with temporary flooding, associated with the ebb and flow of water. In contrast, Wilson et al. [2003,] conducted field measurements under which they examined the use of a resistance force in order to model the interaction of the flow of natural vegetation. In order to determine this force there 
should be a fixed surface extending a plant that is a function of the height of the plant.

The presence of vegetation on the floodplain may affect the velocity distributions in the areas free of vegetation, where it is a dynamic factor causing high variability of flow conditions during the year, under conditions of flow rate changes. This is related to the biometrics and mechanical characteristics of plant species [Dąbkowski 1995]. In such a system there are numerous feedback relations.

The influence of vegetation on water movement resistance in the floodplain is dependent on the density and height of plants, and flow rate of the water, which in turn are affected by flow resistance [Bednarczyk and Duszyński 2008]. Resistance rates are expressed by coefficients, such as the roughness coefficient $n$ and the resistance coefficient $\lambda$. The roughness coefficient $n$ value depends inter alia on the shape of the bottom of the riverbed, the cross-sectional shape changes of the trough and its degree of overgrowth. In contrast, the resistance coefficient $(\lambda)$ value is dependent on the parameters of the vegetation - the diameter and spacing - and on the resistance of the bottom itself.

To determine the resistance of vegetation, ordered parameters were adopted in line with the average diameter of the branches and the average (in the flow direction and opposite) spacing. The flow resistance of partially submerged vegetation is mainly associated with resistance of the object being flown around. It was confirmed experimentally that the flow resistance of high vegetation irregularly distributed can be calculated on the basis of the same number of plants regularly spaced and assuming averaged geometrical parameters [Pasche 1984, Kubrak and Kozioł 2001]. This simplification is introduced due to the difficulty in determining the diameter of twigs and random distribution of plants in the area. Vegetation cover parameters can be estimated by research field, plain photographs or cartographic materials.

To determine the roughness coefficient $\mathrm{n}$ the following methods are used [Iron and Popek 2002]:

- the use of empirical formulas, e.g.: the Cowan equation where the total value of the coefficient $n$ consists of a partial roughness coefficient taking into account, inter alia, change in the shape of the cross section of the trough, irregular edges, the degree of obstruction of the trough; this method also is subject to significant error subjectivity section analyzed by the researcher; the Petryka and Bosmajiana equa- tion [Petryk and Bosmajian 1975] pattern and taking into account the impact of plant density and the effect of the roughness of the substrate or Temple et al. formula [Dąbkowski and .Popek 1995] describing the toughness of the vegetation and soil, after which the water flows,

- selection of the appropriate value from the table (Ven Te Chow tables, Chowe 1959) based on the characteristics of the channel. There is, however, a certain freedom and subjective selection of appropriate values of $n$. Therefore, it is recommended to have some experience, in order to eliminate the possibility of error making,

- the use of previously prepared hydrometric measurements.

Another parameter that describes the characteristics of the flow of water through the vegetation is the resistance coefficient $\lambda$, which can be determined, inter alia, based on the general law of movement according to Colebrook-White and using the Rickert formula. Both formulae are based mainly on the hydraulic radius and do not take into account the height distribution of vegetation. These equations concern the averaged geometrical parameters of vegetation. Coefficient $\lambda$, according to the Pasche formula, is based on the sum of the coefficients related to the roughness of the bottom and walls of the trough and the influence of the geometrical parameters of vegetation. Fathi-Maghadam and Kouwen [1997] and Yen [2002] referred that the density of partially submerged vegetation is always a dominant factor in the determination of the resistance of movement during internal flow - irrespective of tree species distribution, and the shape of the leaves.

\section{MATERIAL AND METHODS}

For the purposes of the research a model floodplain covered by shrubby vegetation has been adopted. This vegetation in the first variant was described by roughness coefficients and in the other - by geometrical parameters (drag coefficient). For a given roughness coefficient (taken from Ven Te Chow tables) the velocity value was determined using the Manning formula. The second option was to determine the average velocity using the Darcy-Weisbach equation. Movement resistance was determined by calculating the ratio $\lambda$ based on the distribution and geometry of plants. The aim of the calculations was to compare the 
average velocities for a model of the inundated land based on two different means of resistance calculation. The different growing season durations were assumed for calculations. The growing season duration influences the resistance value, which is confirmed in the studies conducted by Negma et al. [2002] and Rhee et al. [2008]. For the purposes of calculations a model trough with the area of floodplain was assumed (Figure 1).

The assumed value of roughness used in the calculation of average velocity is presented in Table 1, also taking into consideration the growing season and spacing.

Another parameter used to determine the influence of vegetation on the velocity value is the drag coefficient, which takes into account the diameter of the plants and its geometric distribution in the flood plain (spacing). For the analyzed variants, the following geometric parameters of the vegetation have been assumed: diameter $d_{p}=0.02$ $\mathrm{m}$ and a constant distance between the bushes in the flow direction and $x$ equal $0.20 \mathrm{~m}$ and variable in the direction perpendicular to the direction of flow $a_{y}$ of $0.1 \mathrm{~m} ; 0.15 \mathrm{~m} ; 0.2 \mathrm{~m}, 0.25 \mathrm{~m}$ (Figure 2 ). The depth of the submergence of the shrubby vegetation of floodplains was assumed $0.5 \mathrm{~m}$ and the slopes of water surface $i=0.001$.

\section{RESULTS AND DISCUSSION}

Shrubby vegetation in the second calculation variant was determined by the geometric parameters that were used to determine the resistance coefficient (Table 1). The velocity values calculated from the Maninng equation were shown in Table 2 . The close relationship between the velocity and the period of development of vegetation on the floodplain can be seen. Out of the growing season, in the absence of leaves, shrubby vegetation has a lower coefficient of roughness, and a higher flow rate. The opposite trend can be observed in the summer, where the water flowing through the floodplain densely covered with vegetation loses its velocity.

The dependence of the average velocity of roughness coefficient for the winter and summer at flooding area submergence to a depth of $0.5 \mathrm{~m}$ is shown in Figure 3. An evident decrease can be seen in the velocity of water flow in the flood area with the increase in roughness factor: $n$. The lowest velocity $(0.65 \mathrm{~m} / \mathrm{s})$ and the highest roughness coefficient $\left(0.15 \mathrm{~m}^{-1 / 3} \cdot \mathrm{s}\right)$ occurs during the growing season, assuming the greatest growth of foliage.

The obtained values of average velocity using the Darcy-Weisbach equation - were shown in Table 3. The calculations include different densities of plants and different durations of vegetation period. The flow velocity increases with decreasing density, which was determined based on the average distance.

Figure 4 graphically depicts how the average velocity depends on the drag coefficient, which is in the range of $0.897-2.817$. The stage of plant growth also confirms the assumption that the foliage reduces the velocity and increases the resistance.

The resulting coefficient values cannot be compared with each other, due to the dimensionless resistance coefficient $\lambda$ and dimensional roughness

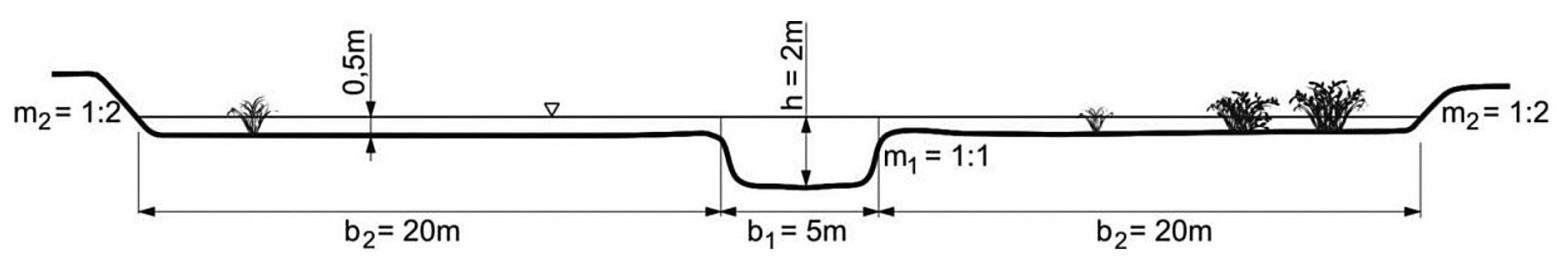

Figure 1. Cross-section Scheme of the Warta River with marked values assumed for calculation

Table 1. Values of roughness coefficient

\begin{tabular}{|c|c|c|l|}
\hline Vegetation season & $\begin{array}{c}\text { Roughness } \\
\text { coefficient } \\
{\left[\mathrm{m}^{-1 / 3} \mathrm{~s}\right]}\end{array}$ & $\begin{array}{c}\text { Spacing } \\
\mathrm{a}_{\mathrm{x}} \times \mathrm{a}_{\mathrm{y}} \\
{[\mathrm{m}]}\end{array}$ & \multicolumn{1}{|c|}{ Description } \\
\hline \multirow{3}{*}{ Winter } & 0.03 & $0.2 \times 0.1$ & willow of high density \\
\cline { 2 - 4 } & 0.035 & $0.2 \times 0.15$ & willow of medium density (minimum value of the coefficient) \\
\cline { 2 - 4 } & 0.07 & $0.2 \times 0.25$ & willow of small density \\
\hline \multirow{3}{*}{ Summer } & 0.08 & $0.2 \times 0.1$ & dense willow grove \\
\cline { 2 - 4 } & 0.1 & $0.2 \times 0.15$ & willow of medium to high density \\
\cline { 2 - 4 } & 0.15 & $0.2 \times 0.25$ & willow of small density (maximum value of the coefficient) \\
\hline
\end{tabular}




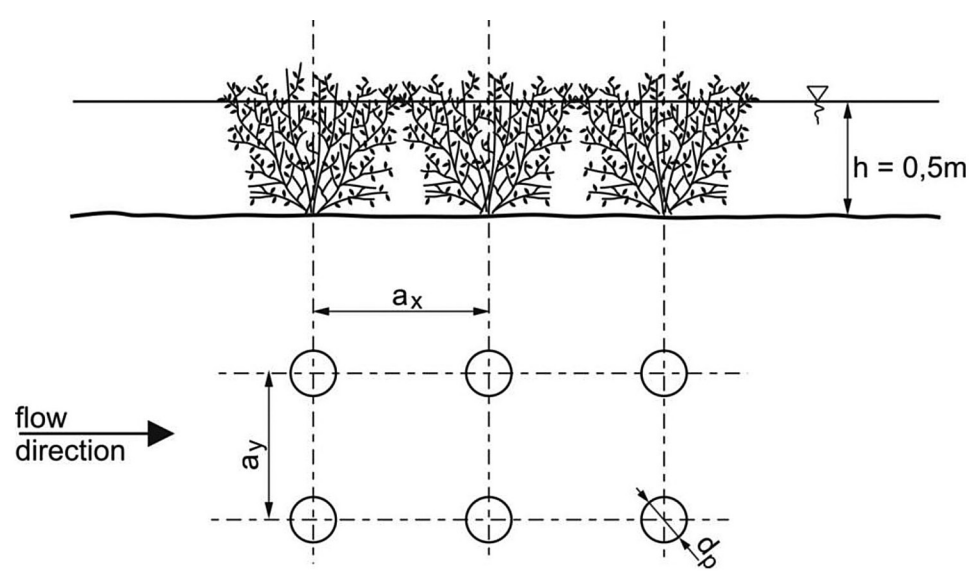

Figure 2. Scheme for the calculation of average velocity in relation to different spacing of vegetation $\left(\mathrm{a}_{\mathrm{y}}\right)$ and submergence depth in the summer and winter

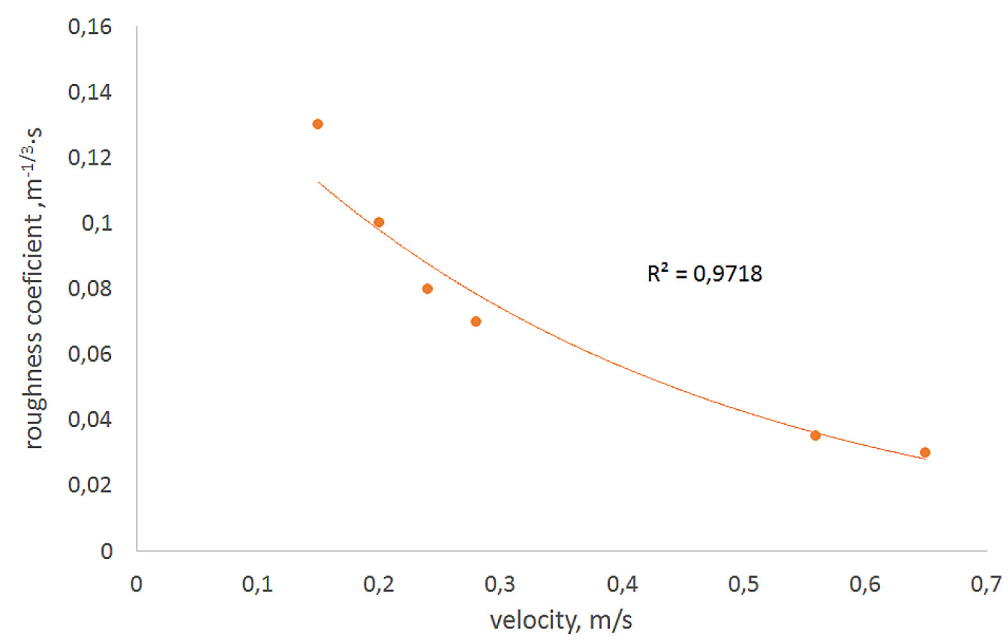

Figure 3. Dependence of average velocity from roughness coefficient for winter and summer

Table 2. Velocity values calculated, based on a different roughness coefficient in summer and winter

\begin{tabular}{|c|c|c|c|}
\hline Cross section & Roughness coefficient $\left[\mathrm{m}^{-1 / 3} \cdot \mathrm{s}\right]$ & Depth [m] & Velocity $[\mathrm{m} / \mathrm{s}]$ \\
\hline \multicolumn{4}{|c|}{ Winter } \\
\hline \multirow{3}{*}{ Flood area } & 0.03 & \multirow{3}{*}{0.5} & 0.65 \\
\hline & 0.035 & & 0.56 \\
\hline & 0.07 & & 0.28 \\
\hline \multicolumn{4}{|c|}{ Summer } \\
\hline \multirow{3}{*}{ Flood area } & 0.08 & \multirow{3}{*}{0.5} & 0.24 \\
\hline & 0.1 & & 0.2 \\
\hline & 0.15 & & 0.13 \\
\hline
\end{tabular}

Table 3. Velocity values calculated based on different resistance coefficients in the summer and winter

\begin{tabular}{|c|c|c|c|}
\hline Cross section & Depth [m] & Resistance coefficient [-] & Velocity $[\mathrm{m} / \mathrm{s}]$ \\
\hline \multicolumn{4}{|c|}{ Winter } \\
\hline \multirow{3}{*}{ Flood area } & \multirow{3}{*}{0.5} & 1.484 & 0.23 \\
\hline & & 1.117 & 0.27 \\
\hline & & 0.897 & 0.3 \\
\hline \multicolumn{4}{|c|}{ Summer } \\
\hline \multirow{3}{*}{ Flood area } & \multirow{3}{*}{0.5} & 2.817 & 0.17 \\
\hline & & 1.884 & 0.21 \\
\hline & & 1.417 & 0.24 \\
\hline
\end{tabular}




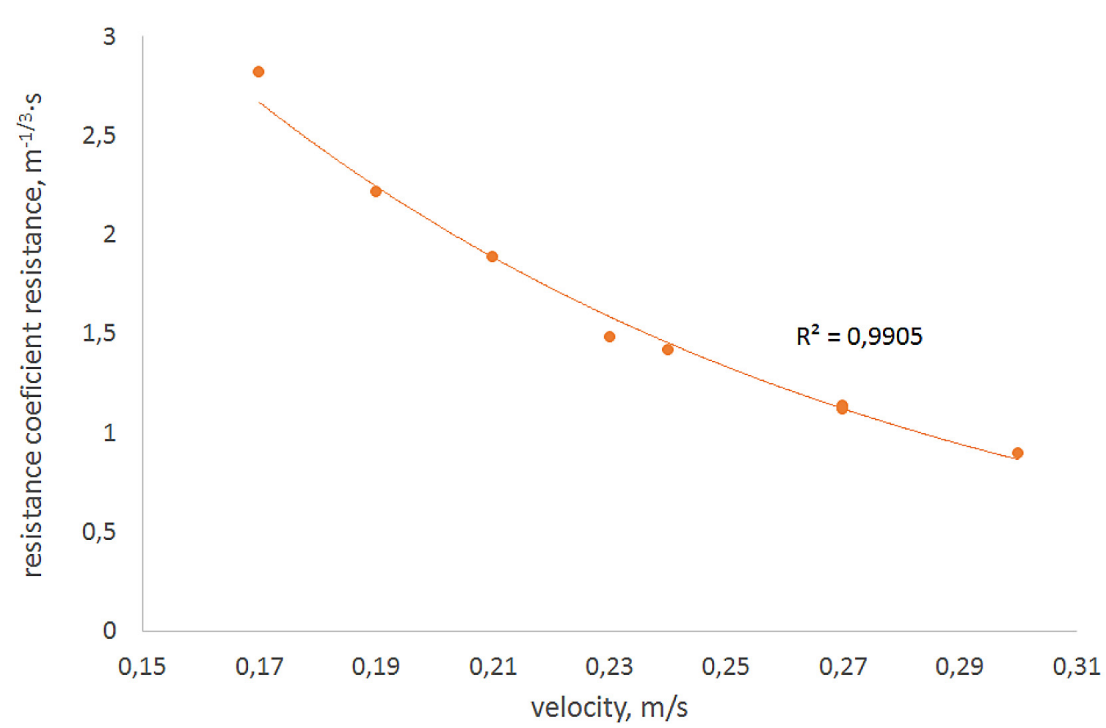

Figure 4. Dependence of average velocity on the resistance coefficient for winter and summer

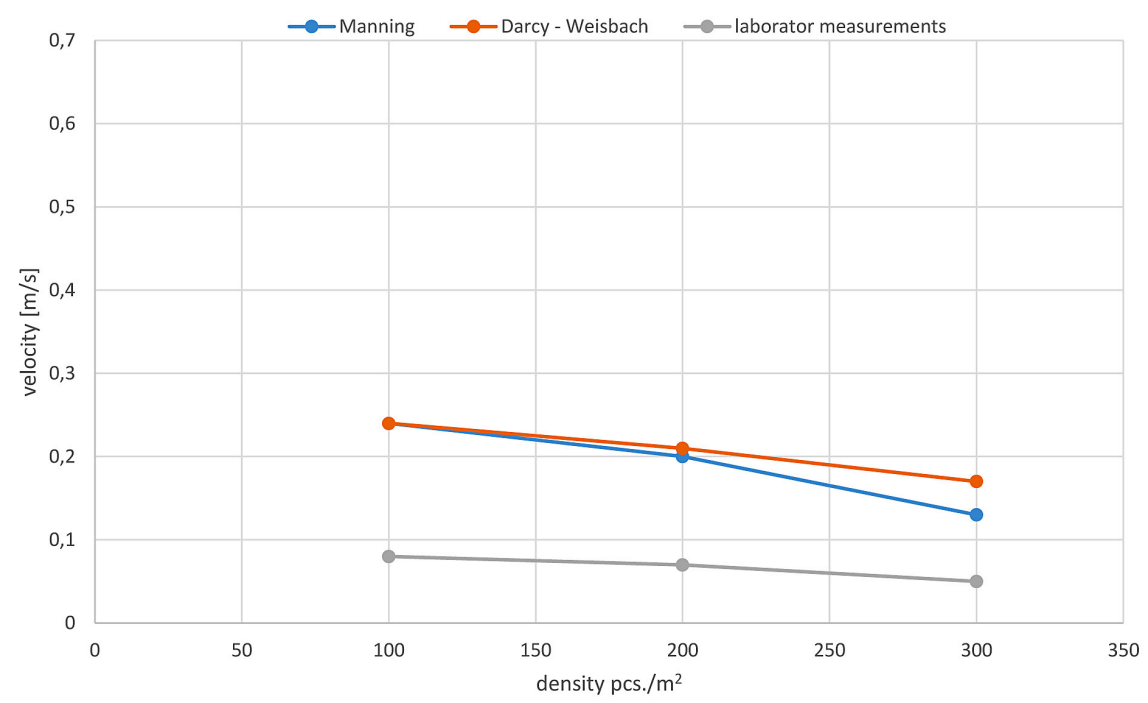

Figure 5. Dependence of average velocity on the density for the summer period

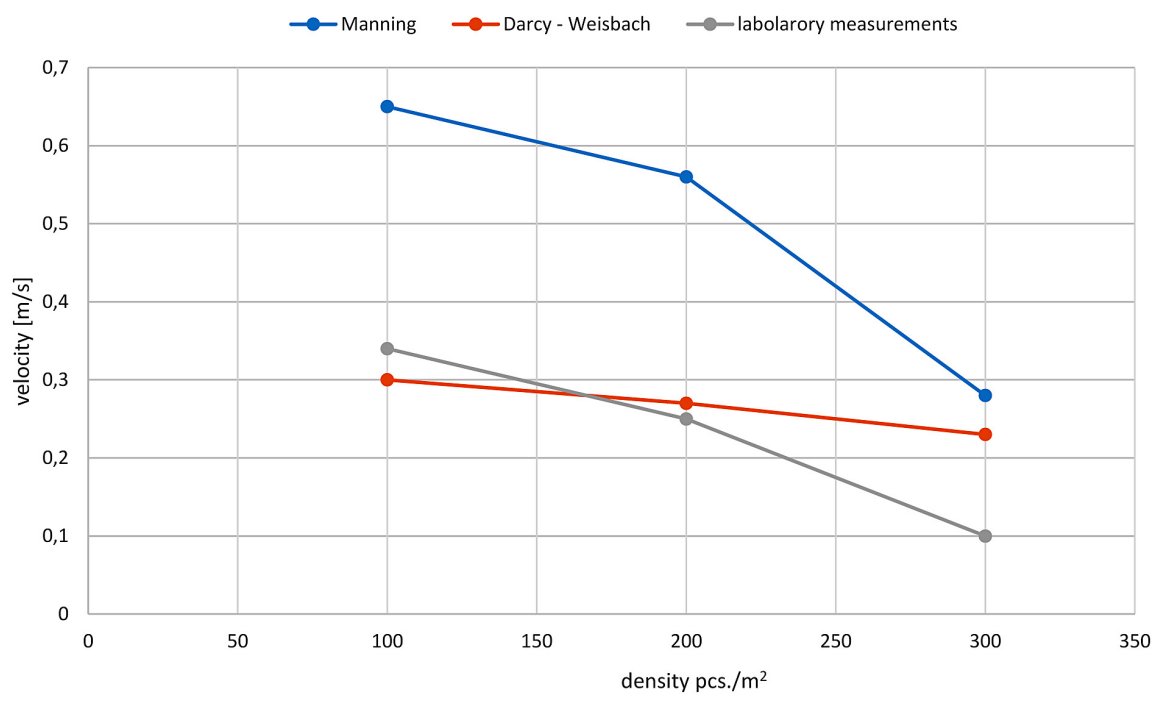

Figure 6. Dependence average velocity on the density for the winter period 
factor $n\left(\mathrm{~m}^{-1 / 3} \mathrm{~s}\right)$. However, the designated velocity for individual variants and corresponding computational density of plants taking into account the vegetation period (Figure 5) and out of vegetation season (Figure 6) can be compared.

Based on the analysis of Figure 6 it can be seen that all the average velocity values determined in different variants decrease with increasing density. In addition, by comparing the velocity value determined empirically with velocity obtained during laboratory tests, significant differences in the velocity (almost 2 times) in the region exhibiting the lowest density can be observed. Differences between velocities designated using various methods decrease as density increases.

The velocities calculated using the Manning and Darcy-Weisbach equations and determined in the laboratory in dependence of vegetation density in winter season were compared in Figure 7. The velocity values calculated based on the Manning equation differ significantly from values obtained from the Darcy-Weisbach equation and laboratory measurements. The least convergent results were obtained for the smallest density.

\section{CONCLUSIONS}

Based on the predetermined channel geometry, the calculations of average velocity were performed for various drag coefficients depending on the density and vegetation development stage. Based on the performed analysis, it can be noted that the vegetation growing on the flood plains has a significant impact on the average value of velocity, which depends mainly on season-related vegetation density. Comparing the velocities calculated empirically (Manning or Darcy-Weisbach equation) with velocities obtained from laboratory tests, a better convergence can be seen during the growing season than during the out-of-growing season. In this context the foliage of floodplain shrubs significantly affects the accuracy of the obtained results. It can therefore be assumed that the nature of foliage determines the average velocities (compensation of the discrepancy during the summer).

\section{REFERENCES}

1. Andersen K.H., Mork M., Nilsen J.E.Ø. 1996. Measurement of the velocity-profile in and above a forest of Laminaria Hyperborea. Sarsia, 81, 193-196.
2. Baptist M.J. 2003. A flume experiment on sediment transport with flexible, submerged vegetation. International workshop on RIParian FORest vegetated channels: hydraulic, morphological and ecological aspects. Trento, Italy.

3. Bednarczyk S., Duszyński R., 2008. Hydrauliczne i hydrotechniczne podstawy regulacji i rewitalizacji rzek. Wyd. Politechniki Gdańskiej, Gdańsk.

4. Chow V.T. 1959. Open-channel hydraulics. McGraw-Hill, New York.

5. Dąbkowski L. 1995. Badania szorstkości hydraulicznej i odporności powierzchni trawiastej na ruch wody. Seminarium nt. „Hydrauliczne i ekologiczne problemy inżynierii rzecznej", materiały seminaryjne, p. E1-E9.

6. Dąbkowski L, .Popek Z. 1995. Wymiarowanie koryta $\mathrm{Z}$ roślinnością trawiastą Seminarium nt. „Hydrauliczne i ekologiczne problemy inżynierii rzecznej", materiały seminaryjne, p. F1-F12

7. Defina A., Bixio Ch. 2005. Mean flow and turbulence in vegetated open channel flow. Water Resources Research, 41, 1-12.

8. Fathi-Maghadam M., Kouwen N. 1997. Nonrigid, nonsubmerged, vegetative roughness on floodplains. Journal of Hydraulic Engineering, 123, 51-57.

9. Gambi M.C., Nowell A.R.M., Jumars P.A. 1990. Flume observations on flow dynamics in Zostera marina (eelgrass) beds. Marine Ecology Progress Series, 61, 159-169.

10. Ghisalberti M., Nepf, H. 2004. The limited growth of vegetated shear-layers. Water Resources Research, 40.

11. Howe A., Rodriguez J. 2006. Flow resistance in saltmarsh and mangrove vegetation in an Australian coastal wetland. 7th International Conference on HydroScience and Engineering Philadelphia, USA.

12. Huthoff F., Augustijn D.C M., Hulscher S.J.M.H. 2007. Analytical solution of the depth-averaged flow velocity in case of submerged rigid cylindrical vegetation. Water Resources Research, 43.

13. James C.S., Birkheaf A.L., Jordanova A.A., O'Sullivan J.J. 2004. Flow resistance of emergent vegetation. Journal of Hydraulic Research, 42(4), 390-398.

14. James C.S., Goldbeck U.K., Patini A., Jordanova A.A. 2008. Influence of foliage on flow resistance of emergent vegetation. Journal of Hydraulic Research, 46(4), 536-542.

15. Järvelä J. 2002. Flow resistance of flexible and stiff vegetation: a flume study with natural plants. Journal of Hydrology, 269, 44-54.

16. Järvelä J. 2003. Influence of vegetation on flow structure in floodplains and wetlands. SánchezArcilla A. and Bateman A. (Eds.). Symposium on River, Coastal and Estuarine Morphodynamics. 
IAHR, Madrid.

17. Jordanova A.A. James C.S., 2003. Experimental study of bed load transport through emergent vegetation. Journal Hydraulic Engineering, ASCE 129, 474-478.

18. Kałuża T., 2000. Opory ruchu przy przepływie wód wielkich wywołanych roślinnością terenów zalewowych. Maszynopis rozprawy doktorskiej, AR. Poznań.

19. Kubrak E. 2007. Rozkłady prędkości wody w korytach otwartych z elementami symulującymi roślinność. Maszynopis rozprawy doktorskiej, SGGW Warszawa.

20. Kubrak E., Kubrak J., Rowiński P. M. 2008. Vertical velocity distributions through and above submerged, flexible vegetation. Hydrological Sciences Journal des Sciences Hydrologiques, 53(4), 905-919.

21. Kubrak J., Kozioł A. 2001. Wyniki obliczeń prędkości w przekroju dwudzielnym z drzewami w terenie zalewowym. Przegląd Naukowy Wydziału Melioracji i Inżynierii Środowiska, 23, 3-11.

22. Leonard L.A., Luter M.E. 1995. Flow hydrodynamics in tidal marsh canopies. Limnology and Oceanography, 40(8), 1474-1484.

23. Lopez F., Garcia M.H. 2001. Mean flow and turbulence structure of open-channel flow through non-emergent vegetation. Journal of Hydraulic Engineering, 127, 392-402.

24. Meijer D.G., van Velzen E.H. 1999. Prototypescale flume experiments on hydraulic roughness of submerged vegetation. In $28^{\text {th }}$ International IAHR Conference, Graz.

25. Negm A.M., Ibrahim A.A., El-Saiad A.A., Al-Brahim A.M. 2002. Flow resistance due to cylindrical piles. 5th International Conference on Hydro -Science \& -Engineering 2002 Warszawa.

26. Nepf H.M., Koch E.M. 1999. Vertical secondary flows in submersed plant-like arrays. Limnology and Oceanography, 44(4), 1072-1080.

27. Nepf H.M., Vivoni E.R. 1999. Turbulence structure in depth-limited, vegetated flow: transition between emergent and submerged regimes. Proceedings of the 28th IAHR Congress Graz, Austria.

28. Pasche E. 1984. Turbulenzmechanismen in naturnahen Fliessgewässern und die Möglichkeit ihrer mathematischen Erfassung. Mitteilungen des Instituts für Wasserbau und Wasserwirtschaft, RHWT Aachen, Zeszyt 52.
29. Rameshwaran P., Shiono K. 2007. Quasi twodimensional model for straight overbank flows through emergent vegetation on floodplains. Journal of Hydraulic Research, 45(3), 302-315.

30. Rhee D., Woo H., Kwon B., Ahn H. 2008. Hydraulic resistance of some selected vegetation in open channel flows. River Research and Applications, 24, 673-687.

31. Righetti M., Armanini A. 2002. Flow resistance in open channel flows with sparsely distributed bushes. Journal of Hydrology, 269, 55-64.

32. Rowiński P.M., Kubrak J. 2002. Velocity profiles on vegetated flood plains. Proceedings of the International Conference on Fluvial Hydraulics, River Flow, 2002, 303-309.

33. Government Security Centre in Polish. Rządowe Centrum Bezpieczeństwa, 2013. Ocena ryzyka na potrzeby zarządzania kryzysowego. Raport o zagrożeniach bezpieczeństwa narodowego. Warszawa. http://rcb. gov.pl/wp-content/uploads/ocenaryzyka.pdf

34. Shimizu Y., Tsujimoto T. 1994. Numerical analysis of turbulent open-channel flow over a vegetation layer using a $k-\varepsilon$ turbulence model. Journal of Hydroscience and Hydraulic Engineering, 11(2), 57-67.

35. Stephan U., Gutknecht D. 2002. Hydraulic resistance of submerged flexible vegetation. Journal of Hydrology, 269, 27-43.

36. Stone B. M., Shen H. 2002. Hydraulic resistance of flow in channels with cylindrical roughness. Journal of Hydraulic Engineering, 128(5), 500-506.

37. Tsujimoto T., Shimizu Y., Kitamura T., Okada T. 1992. Turbulent open-channel flow over bed covered by rigid vegetation. Journal Hydroscience and Hydraulic Engineering, 10(2), 13-25.

38. Wilson C.A.M.E., Stoesser T., Bates P.D., Batemann Pinzen A. 2003. Open channel flow through different forms of submerged flexible vegetation. Journal of Hydraulic Engineering, 129(11), 847-853.

39. Wu F.C., Shen H.W., Chou Y.J. 1999. Variation of roughness coefficient for unsubmerged and submerged vegetation. Journal of Hydraulic Engineering, 125(9), 934-942.

40. Yen B. 2002. Open Chanel flow resistance. Journal of Hydraulic Engineering, 128(1), 20-39.

41. Żelazo J., Popek Z., 2002. Podstawy renaturyzacji rzek. Wydawnictwo SGGW Warszawa. 